\title{
МЕТОДОЛОГІЧНИЙ АСПЕКТ РОЗВИТКУ МЕТОДИКИ НАВЧАННЯ ІСТОРІЇ В УКРАЇНСЬКИХ ШКОЛАХ ГАЛИЧИНИ У ДРУГІЙ ПОЛОВИНІ ХІХ - ПЕРШІЙ ТРЕТИНІ ХХ СТ.
}

Савшак Т. М. Методологічний аспект розвитку методики навчання історії в українських школах Галичини у другій половині XIX - першій третині XX ст.

У статті виявлено й обгрунтовано методологічні аспекти розвитку методики навчання історії в українських школах Галичини у другій половині XIX - початку XX ст. Автор визначає культурно-історичні обставини розвитку галицької педагогіки в досліджуваний період, вказує на вплив ідей «нового виховання».

Ключові слова: методологічна основа, реформаторська педагогіка, навчання історії, виховання, методика, національна ідея.

Савшак Т. М. Методологический аспект развития методики обучения истории в украинских школах Галичины во второй половине XIX - первой трети XX в.

В статье выявлены и обоснованы методологические аспекты развития методики обучения истории в украинских школах Галичины во второй половине XIX - начале XX в. Автор определяет культурно-исторические условия развития галицкой педагогики в исследуемый период, указывает на влияние идей «нового воспитания».

Ключевые слова: методологическая основа, реформаторская педагогика, обучение истории, воспитание, методика, национальная идея.

Savshak T. M. Methodological aspect of teaching methods in the history of Ukrainian schools of Galicia in the second half of XIX - the first third of the twentieth century.

The paper established and developed methodological aspects of teaching methods in the history of Ukrainian schools of Galicia in the second half of the XIX - early XX century. The author defines the cultural and historical conditions of the Galician pedagogy in the survey period, indicates the influence of the ideas of the «new education».

Key words: methodological framework Reformed teaching, the teaching of history, education, methodology, national idea.

Діалектика історико-культурного розвитку теорії та методики навчання історії та суспільствознавчих дисциплін як галузі наукового педагогічного знання визначає нині необхідність дослідження розвитку методики навчання історії в українських школах Галичини у другій половині XIX - першій третині XX ст., доцільне використання досвіду педагогів минулого в сучасних умовах. Методологічний аспект проблеми визначає те, що система шкільної історичної освіти в українських школах Галичини зазначеного періоду, етнічні українські землі якої входили до культурного кола різних метрополій (Австро-Угорщина, Польща), формувалася у світовому контексті виникнення та утвердження ідей реформаторської педагогіки, подолання недоліків «традиційної» школи.

Стан розробленості проблеми виявляє два рівні ії дослідження: 1) синхронний (емпіричний) i 2) діахронний (теоретичний). На першому, емпіричному, рівні досліджуваної проблеми виявляємо праці тих, хто безпосередньо в досліджуваний період вивчав і популяризував на освітніх теренах Галичини ідеї реформаторської педагогіки шляхом теоретичних розробок і практичної реалізації, визначав методологію, створював методику навчання історії в галицьких українських школах. Це програми, методичні поради, підручники, публікації в педагогічних україно- та польськомовних часописах («Muzeum» («Музей», 1885-1939), «Szkola» («Школа», 1868-1939), «Rodzina i Szkola» («Родина і школа», 1896-1913), «Шкільний часопис» (18801889), «Учитель» (1889-1914), «Шлях навчання та виховання» (1927-1939), «Методика і шкільна практика» (1921-1939) з проблем навчання історії та суспільствознавчих дисциплін, авторами яких були Т. Біленький, Г. Врецьона, М. Галущинський, В. Залужний, С. Ковалів, Я. Кузьмів, М. Куцій, Т. Лопушанський, М. Макух, І. Мацюк, Р. Моленда, М. Надпрутянський, М. Рамултова, С. Русова, Ст. Сірополко, К. Чайківський, В. Чорномаз, І. Ющишин та інші. На 
другому, теоретичному, рівні вивчення проблеми виокремлюємо праці про розвиток методики навчання історії в українських школах Галичини у другій половині XIX - першій третині $\mathrm{XX}$ ст. Найбільш широко і повно висвітлено історико-культурний процес становлення методики шкільної історичної освіти та вивчення історії в загальноосвітній школі у Галичині у другій половині XIX - поч. XX ст. у працях О. Пометун [6, 7]; I. Курляк розв'язала проблему розвитку класичної освіти на західноукраїнських землях (XIX - перша половина XX століття) на прикладі діяльності класичних гімназій у Галичині [3]; В. Стинська проаналізувала систему шкільництва в Галичині (кінець XIX - початок XX ст.) [9]. Розв'язання проблеми розвитку методики навчання історії в Галичині у другій половині XIX - першій третині XX ст. грунтується на дослідженняХ історії педагогіки, зокрема реформаторської, основних положеннях теорії навчання і виховання. Це праці М. Антонця, Л. Баїк, А. Бондара, О. Вишневського, М. Свтуха, О. Караманова, Н. Калениченко, Г. Кемінь, В. Кравця, В. Майбороди, Б. Мітюрова， Н. Ничкало， Ю. Руденка, М. Стельмаховича, Б. Ступарика, М. Чепіль, М. Ярмаченка та інших. Однак методологічний аспект проблеми розвитку методики навчання історії в українських школах Галичини у другій половині XIX - першій третині XX ст. залишається нерозглянутим, зокрема 3 урахуванням досвіду і в контексті ідей світової реформаторської педагогіки кінця XIX - початку XX ст.

Метою статті $є$ виявлення та обгрунтування методологічного аспекту розвитку методики навчання історії в українських школах Галичини у другій половині XIX - першій третині XX ст.

Навчання історії, суспільствознавчих дисциплін та пошук ефективних методик цього процесу у другій половині XIX - першій третині XX ст. були визначені теоретикометодологічними засадами різних напрямів світової реформаторської педагогіки, зокрема: педагогіки культури (В. Дільтей), педагогіки дії (В. Лай, О. Декролі), у теорії громадянського виховання і трудової школи (Г. Кершенштайнер), прагматичної педагогіки (Дж. Дьюї) та функціональної педагогіки (Е. Клапаред), як одні із найважливіших проблем у процесі формування гармонійно і всебічно розвиненої особистості, громадянина і творця культури.

Реформаторська педагогіка, як зазначає О. Сухомлинська, - це різнорівневий і різнобічний рух, до якого входило багато педагогічних напрямів і течій, які розробляли різні шляхи реформування школи, спиралися на педоцентричні позиції і вільний розвиток особистості, зокрема: експериментальна педагогіка, що будувала свою концепцію на кількісних методах природничих наук; трудова школа з її ідеями активізму та мануалізму й підготовки до життя; соціальна педагогіка П. Наторпа, який підкреслював суспільний характер виховання та його зумовленість суспільним життям; педагогіка особистості Г. Гаудіга, який розробляв ідеї художньо-творчого розвитку особистості на основі самодіяльності і творчості. Рух за реформу школи був об'єднаний у 1921 р. у міжнародну організацію «Ліга нового виховання», яка на початку 20-х рр. XX ст. мала близько 50 секцій, що працювали у різних країнах світу, публікувала свої видання на 15 мовах. У 1925 р. було створено Міжнародне бюро освіти, яке поставило своїм завданням широку популяризацію тогочасних досліджень Г. Кершенштайнера, О. Декролі, М. Монтессорі, Дж. Дьюї та ін. [10, с. 774]. У країнах Західної Європи цей рух отримав назву нового виховання, у Німеччині - педагогіки реформ, у США - прогресивізму.

Ідеї реформаторської педагогіки популяризували друковані видання в Європі та США: «Педагогічний щорічник міжнародного інституту вчителів» («Educational Yearbook of the International Institute of Tearhers College», Нью-Йорк), «Міжнародний науковий журнал 3 виховання» («Internationale Zeitschrift fur Erzieungswissenschaft, Кельн), «Нова ера» («The New Era», Лондон), «За нову еру» («Pour I'Ere Nouvelle», Женева), «Майбутнє століття» («Das Werbende Zeitalter», Берлін), «Приятель школи» («Przyjaciel szkoly», Варшава), «Шлях навчання і виховання»(Львів) та ін.

Проблема історичної освіти у концепції «нового виховання» вимагала зробити працю учня більш самостійною, змінити методику викладання, передбачивши використання активних методів, оскільки, за словами В. Лая, «таємниця навчання - в дії», здійснити перерозподіл матеріалу на окремі роки навчання, детально переглянути навчальний матеріал тощо. Нову методику вивчення історії в досліджуваний період запропонував Дж. Дьюї: історія у школі - не формальна добірка виключно фактів, а динамічна наука, що допомагає дитині відтворити образ розвитку людства упродовж віків; в історії важлива не біографія історичної особи, а економічні і господарські стосунки на тлі історії; дитина повинна уявити себе на місці первісної людини і відстежувати поступ та розвиток людства, знову «винаходити» різні знаряддя, спостерігати за їх удосконаленням, учитися ними користуватися. Така методика вчить думати, робити висновки, 
використовувати творчі задатки, ручну працю. Залучення та активне використання фізичних сил дитини під час вивчення історії пропонував Г. Кершенштайнер (моделювання будівель, ілюстрування подій, реконструювання тощо), однак уважав, що у старших класах учні повинні здобувати знання так, як їх здобуває історик, - за допомогою читання та інтерпретації історичних джерел. О. Декролі пропонував вивчати історію навколо так званих «осередків зацікавлення», тобто таких тем, як родина, школа, звірі, рослини, суспільство тощо [11, с. 570-574].

Галицькі педагоги-реформатори визначали мету і методологію шкільної освіти, історичної зокрема, у настановах ідей реформаторської педагогіки та національної української ідеї, що було пов'язано з колоніальною залежністю галицьких земель та тогочасним станом освіти в Галичині. Саме тому в Основних тезах Резолюцій і постанов Першого українського педагогічного конгресу (Львів, 1935 р.) чітко визначено мету і завдання національного виховання в народній школі, яка, як вказано у Резолюціях і постановах Першого українського педагогічного конгресу, не суперечить загальнолюдським цінностям та ідеалам: «1) ... право на національне виховання - це самозрозуміла життєва необхідність для розвитку нації. Здійснювати його може тільки рідна виховна установа 3 рідним виховником. 2) Метою національного виховання української молоді є всебічна підготовка ії̈ до здійснення найвищого ідеалу нації, до чинної творчої участи в розбудові рідної духової й матеріяльної (тут і надалі збережено правопис оригіналу - прим. Т.С.) культури, а через неї до участи у вселюдській культурі». Тут же в межах «шкільної політики» визначено завдання, які також пов'язані 3 національним питанням: «1) ...добути українському народу в Польщі відповідну кількість шкіл усіх категорій, типів і щаблів, починаючи з установ дошкільного виховання, аж до університету і шкіл академічного ступня, згідно з чисельним станом українського народу та виховноосвітніми його потребами; 2) ...уможливити українським школам усіх категорій, типів і щаблів ...нормальний доплив потрібної кількости кваліфікованого вчительства української народности; 3) ...поробити всі потрібні заходи для негайного заснування високих українських шкіл - зокрема університету i хліборобсько-економічної академії; 4) ...вибороти для українського народу в Польщі право самому дбати про виховання своєї шкільної молоді...; 5) ...прийняти в виховній практиці одноцілий провід «Рідної Школи»; 6) ... проти втягання шкільної молоді в які-небудь політичні організації; 7) ... подбати про затвердження наукових програм для українських народніх і середніх шкіл про навчання української мови, історії, географії та предметів мистецького і фізичного виховання ... 8) ... скасування двомовности в усіх школах і установах, де виховується українська молодь; 9) скасування перепон у розбудові українського приватного шкільництва та виховно-освітніх установ; 10) допущення українських виховних, освітніх і господарських установ до організації дошкільного й позашкільного виховання, доповняючої освіти та домашнього навчання; ... 11) ... щоб українська преса присвятила справам виховання більше уваги, та вияснила широким кругам українського громадянства важливу суспільну функцію виховання ...» [8, с. 236-249].

Про розвиток педагогічної думки Галичини на методологічних засадах зарубіжного реформаторського руху свідчать публікації в тогочасних галицьких часописах. Зокрема, у «Наукових програмах в народних школах третього ступеня для дітей української національності» сказано про врахування «новочасної» педагогічної доктрини» [5, с. 51]. А у «Проєкті єдиної школи в Україні» автор М. Надпрутянський зазначає, що «проєктодавці брали до уваги найкращі зразки західноєвропейського шкільництва. А Проєкт єдиної школи як цілість - $є$ відгоміном нових педагогічних течій, що по світовій війні (Першій світовій війні прим. Т.С.) появилися в Західній Європі» [4].

Особливістю творення методології та змісту нової школи для галицьких педагогів були суспільно-політичні обставини розвитку галицької педагогічної думки. Залежність від Польщі визначала методологічну настанову погодження програм для дітей української національності 3 польськими програмами. Так, у «Наукових програмах в народних школах третього ступеня для дітей української національности» визначено погодження задач і цілей, методики навчання i виховання «дітей української національности» з інтересами Польської метрополії Галичини: «Зв’язок рисунків, співу з історією, яка викладається з заокругленням знання історії Польщі» [5, с. 70]. Галицькі педагоги прагнули реформувати існуючу систему освіти в Галичині, інтегруючи мету «нового», західноєвропейського виховання 3 великодержавницьким (польським, австро-угорським) та національним українським вихованням. А тому в «Наукових програмах...» зазначено, що «на чільне місце висунуто «місцеві цінності середовища, 
«регіоналізму» [5, с. 51]; що для дидактичного й методичного забезпечення навчання з різних предметів «... мають значення загальні права міжнароднього характеру. А національний характер ... виступить ... в тематиці» $[5$, с. 71$]$.

«Шкільну політику» в складних умовах колоніальної залежності визначали прагнення галицьких педагогів зберегти специфічні українські національні риси галицької педагогіки. В. Кузьмович у виступі на Першому українському педагогічному конгресі стверджує, що «завданням української шкільної політики $є$ реалізувати українські виховні ідеї в умовинах, у яких живе український нарід ... у Польщі». Розмірковуючи над культурно-історичним розвитком Польської держави і водночас Галичини в іiі складі, доповідач висловлює своє переконання, що метою сучасного польського державного виховання є політична мета, яка підпорядковує, а то й нівелює освітню: «перевиховати в напрямі вироблення почуття державної солідарности та одиничної відповідальности за долю держави і в напрямі жертвенної служби державі». У таких обставинах український народ не може реалізувати у школі власні політичні доктрини, оскільки $\epsilon$ бездержавною нацією. Однак у процесі навчання і виховання української молоді, як переконаний автор, може бути втілена національна ідея, «ідея почування зв'язку із власним народом, ідея української культурної і духовної соборности, української національної єдности». А це, в свою чергу, ставить вимогу: «українська школа й український учитель для української дитини». В. Кузьмович ставить питання: «чи в сучасній історичній ситуації українського народу можна національні ідеали цього народу і його культурну творчість, оперту на цих ідеалах, погодити з існуванням польської державности на тутешніх територіях?». I дає на нього відповідь - «найти компроміс поміж польською державністю й українськими природними національними стремліннями», а «українська шкільна політика мусить видвигнути свої тези у справах державного виховання, але у згоді з українською національною політикою». А тому висловлено протест проти «утраквізму» (двомовності) у шкільній практиці, «бо утраквізм $є$ засобом денаціоналізації», водночас поставлено проблему соціальної політики в системі освіти, вказано на те, що «у гімназіях нового типу селянських дітей майже нема (високі оплати у вищих класах), треба допомогти бідним учням ... дістатись до гімназії, закладати дешеві бурси, зраціоналізувати сітки українського приватного шкільництва і подбати про розбудову українського фахового шкільництва», оскільки «молодь повинна припливати рішучо в більшій кількості до гімназій» [2, с. 198-201].

Слід зазначити, що методологічна настанова пошуку компромісу в освіті відповідала політиці українсько-польських взаємин початку ХХ століття, оскільки у лютому 1914 року завдяки активним діям митрополита Андрея Шептицького було укладено польськоукраїнський компроміс, згідно з яким українці повинні були одержати третину місць у галицькому сеймі і повноправне представництво у різних сеймових комісіях. Поляки зобов'язалися не чинити перешкод заснуванню українського університету у Львові [1].

Галицькі педагогічні видання (як україномовні, так і польськомовні) успішно пропагували нові педагогічні теорії, критикуючи гербартизм (як освітню ідеологію «старої», «традиційної» школи, яка асоціювалася з іменем Й. Гербарта) у поняттях, відповідно: примус і визволення, консерватизм і прогрес, авторитаризм і лібералізм. Ідея реформування освіти для галицькоукраїнських педагогів мала не лише педагогічний зміст, а й культурно-політичний, була пов'язана 3 проблемами статусу і вивчення української мови, всесвітньої та історії рідного краю, збереження народних звичаїв та обрядів, релігії та інших ознак національної ідентичності.

Методологічна основа розвитку методики викладання історії як навчальної суспільствознавчої дисципліни у загальноосвітніх українських школах Галичини була зорієнтована на реалізацію націотворчої настанови, давала можливість інтегрувати ії 3 метою навчання, виховання та розвитку особистості. Методика навчання історії в українських школах Галичини опиралася на такі засади «нового виховання»: - навчання $є$ лише засобом виховання, самовиховання та розвитку дитини; - знання про власну історію, географію, літературу, мистецтво тощо є основою навчання і виховання української дитини; - українська шкільна політика - це «компроміс поміж польською державністю й українськими природними національними стремліннями». Проблема історичної освіти у «новому вихованні» в досліджуваний період вимагала поєднання шляху від особистого життєвого досвіду дитини, їі найближчого оточення до його узагальнення з людським досвідом в історії, від предметночуттєвого пізнання до понятійно-раціонального.

Перспективою подальшого дослідження проблеми $\epsilon$ аналіз методико-дидактичного забезпечення навчання історії в українських школах досліджуваного періоду. 


\section{Література}

1. Кобринська М. Українське шкільництво в Коломиї / М. Кобринська // Коломия. Електронний ресурс. - Режим доступу: http://kolomyya.org/histpub /historypub50.htm 2. Кузьмович В. Українська шкільна політика (у скороченні) / В. Кузьмович // Перший український педагогічний конгрес, 1935. - Львів: Накладом товарства «Рідна школа», 1938. - 252 с. - С. 198-201. 3. Курляк I. Розвиток класичної освіти на західноукраїнських землях (XIX-перша половина XX ст.): дис. ... д-ра пед. наук: 13.00.01 / І. Курляк; Інститут педагогіки і психології професійної освіти АПН України. К., 2000. - 473 с. 4. Надпрутянський М. Проєкт єдиної школи в Україні / М. Надпрутянський // Шлях виховання і навчання. - Кн.1, 1938. - Січень-лютий-березень - С. 1-6. 5. Наукові програми в народних школах третього ступеня для дітей української національності //Шлях навчання й виховання. -1934. - кн.1. - С. 7-73. 6. Пометун О. Методика навчання історії в школі / О. Пометун, Г. Фрейман. - К.: Генеза, 2005. - 328 с. 7. Пометун О. Навчання історії без пристрастей і пересудів / О. Пометун // Історія в школах України. - 2002. - № 4. - С. 7-11. 8. Резолюції і постанови Першого українського педагогічного конгресу // Перший український педагогічний конгрес, 1935. - Львів: Накладом товариства «Рідна школа», 1938. - 252 с. - С. 236-249. 9. Стинська В. Система шкільництва в Галичині (кінець XIX - початок XX ст.): дис. ... канд. пед. наук: 13.00 .01 / В. Стинська; Прикарпатський ун-т ім. Василя Стефаника. - Івано-Франківськ, 2004 - 243 с. 10. Сухомлинська О. В. Реформаторська педагогіка / О. В. Сухомлинська // Енциклопедія освіти / Акад. пед. наук України; головний ред. В. Г. Кремень. - К. : Юрінком Інтер, 2008. - С. 774. 11. Nowaczyk S. Rysunekjko ilustracja historji / S. Nowaczyk // Przyjaciel szkoly. - 1929. - S. 570-574.

УДК [378.147:371.26](94)

Тамара Семенченко

\section{ТЕХНОЛОГІЯ ОЦІНЮВАННЯ В СИСТЕМІ ПЕДАГОГІЧНОЇ ПРОФЕСІЙНОЇ ОСВІТИ АВСТРАЛЇ̈}

Семенченко Т. О. Технологія оцінювання в системі педагогічної професійної освіти Австралії.

У статті розглянуто компоненти технології оцінювання в педагогіці вищої школи Австралії. Охарактеризовано теоретико-філософські підходи до оцінювання навчальної діяльності та зв'язку оцінювання з професійною підготовкою майбутніх учителів Австралії.

Ключові слова: оцінювання у вищій школі, формативне та підсумкове оцінювання, завдання для оцінювання майбутніх учителів.

Семенченко Т. А. Технология оценивания в системе педагогического профессионального образования Австралии.

В статье рассмотрены компоненты технологии оценивания в педагогике высшей школы Австралии. Охарактеризированы теоретико-философские подходы к оцениванию учебной деятельности и взаимосвязи оценивания и профессиональной подготовки будущих учителей Австралии.

Ключевые слова: оценивание в высшей школе, формативное и итоговое оценивание, задания для оценивания будущих учителей.

Semenchenko T. O. The assessment technics in the system of teacher professional education in Australia.

The constituent parts of the assessment technics in the system of higher education in Australia are viewed in the article. Theoretic and philosopfic approaches to learning and teaching assessment and the correlation between the assessment and the initial professional teacher training in Australia were characterised.

Key words: assessment in higher education, formative and summative assessment, assessment tasks for future teachers.

Проблема якості освітніх послуг є однією з визначальних для системи освіти будь-якої країни, зокрема й України. В аналітичній записці Національного інституту стратегічних досліджень при Президентові України «Свропейський досвід для створення ефективної системи контролю та оцінки якості вищої освіти» зазначено, що «жоден із чисельних українських ВНЗ не входить до 500 кращих університетів світу за провідними світовими 